\title{
Response of fahl clover to compost rates under irrigation intervals in newly reclaimed saline soils.
}

\author{
Mervat R. I. Sayed ${ }^{1}$, Khaled A. Shaban ${ }^{2}$ \\ 1-Forage Crops Research Department, Field Crops Res. Inst., ARC, Egypt. \\ 2-Soil, Water and Environmental Res. Inst., ARC, Egypt.
}

\begin{abstract}
A field experiment was conducted on saline clay soil located at the experimental Farm of Sahl- ElHoussinia Agriculture Research Station, El-Sharkia governorate, Egypt, during two winter seasons of 2014/2015 and 2015/2016. These experiments aimed to study the effect of irrigation intervals and compost rates alone or combined on soil fertility and fahl clover productivity and quality under newly reclaimed saline soil conditions. The experimental treatments were arranged in a split plot design with four replicates. The main plots represented the three irrigation intervals $(12,16$ and 20 days), whereas the sub-main plots represented compost rates $(0,5$, 10 , and 15 ton/fad). The results revealed that the effect of irrigation intervals and compost rates were positive on all growth traits of fahl clover and saline soil properties during the two seasons.

Irrigation intervals had a significant effect on growth traits and yield of clover crop and maximum values were obtained with the 12 days irrigation interval. On the contrary, minimum values for the corresponding respective characters were recorded with the 20 days irrigation interval.

The increase of compost rate (5, 10 and 15 ton /fad) gave increases of all growth traits and yield compared with the control. Also, the interaction between irrigation intervals and compost rates was significant on all studied traits and yield. The 12 days interval combined with all compost rates gave the highest values of studied growth traits as well as forage yields. Results showed that the application of compost increased the chemical composition contents of clover plants and soil properties after harvest as well.
\end{abstract}

Key Words: Irrigation intervals, compost, growth traits, chemical composition.

\section{Introduction}

Egyptian clover Trifolium alexandrinum L. is the most important winter forage crop in Egypt. It is adapted to a wide range of soil conditions and shows good tolerance to saline and alkaline soils. It is not suitable for acidic or heavy-structured soils.

Soil salinization and drought stress mainly occur in the arid and semiarid regions of Mediterranean area, which are characterized by high evapotranspiration rates and low rainfall. In these areas, the leaching of salts is very low; therefore, salt accumulates in soil surface layers. Since high salts content may adversely influence soil properties and crop yields, food security could be limited as a consequence. Therefore, salt-affected soils must be reclaimed to maintain satisfactory levels of fertility for sustaining food production, Maringela and Francesco (2015).

Water is the most important factor limiting horizontal and vertical expansion in the production of different crops. Crop yield and quality are affected by available water in the soil, El-Nomani et al, (2015). Increasing number of irrigation (irrigation amounts) up to the maximum level increased growth parameters, i.e. plant high, number of branches per plant, leaf area, total plant dry matter, number of flowers, Abdel-Mawgoud (2006) . Water stress decreased the availability of moisture in the soil and this consequently decreased the availability of nutrients and intern affected the absorption of minerals, Hussein and Mahmoud (2013). El-Salam Canal is one of the national promising projects for reusing drainage water in irrigation. Namely, drainage water from Hadous drain $\left(1.905 \mathrm{~B} \mathrm{~m}^{3}\right.$ year$\left.{ }^{1}\right)$ and El-Serw drain $\left(0.435 \mathrm{~B} \mathrm{~m}^{3}\right.$ year $\left.^{-1}\right)$ in a $1: 1$ mixing ratio with the Nile river water $\left(2.11 \mathrm{~B} \mathrm{~m}^{3}\right.$ year $^{-1}$ ) delivered from Damietta branch (Shaban 2005).

Organic matter has several beneficial effects on agricultural fields, such as the slow release of nutrients, soil structure improvement and the protection of soils against erosion. Also, Organic fertilizers are very important for increasing agricultural production, reducing the application rates of chemical fertilizer and hence the prevention of environmental pollution, Reda (2007).

\section{Materials and Methods}

Two field experiments were conducted at Sahl El-Hussinia Agricultural Research Station, ElSharkia Governorate, Egypt, in 2014/2015 and $2015 / 2016$ winter seasons. The objectives of these experiments were aimed to study the influence of irrigation intervals and compost rates on some soil chemical properties and productivity and quality of clover variety fahl under saline soil conditions. Some physical and chemical properties of the study soil were determined according to the methods described by Page $\boldsymbol{e t} \boldsymbol{e l}, \mathbf{( 1 9 8 2 )}$ are presented in Table (1). 
Table 1. Some physical and chemical properties of the soil used.

\begin{tabular}{|c|c|c|c|c|c|c|c|c|c|}
\hline \multicolumn{3}{|c|}{ Sand (\%) } & \multirow{2}{*}{$\frac{\text { Silt }(\%)}{34.90}$} & \multirow{2}{*}{$\frac{\text { Clay }(\%)}{40.46}$} & \multicolumn{2}{|l|}{ Texture } & \multicolumn{2}{|l|}{ O.M $(\%)$} & \multirow{2}{*}{$\frac{\mathrm{CaCO}_{3}(\%)}{8.90}$} \\
\hline 24.64 & & & & & Clay & & 0.53 & & \\
\hline \multirow[t]{2}{*}{ Seasons } & \multirow{2}{*}{$\begin{array}{l}\mathrm{pH} \\
(1: 2.5)\end{array}$} & \multirow{2}{*}{$\begin{array}{l}\mathrm{EC}(\mathrm{dS} / \mathrm{m}) \\
\text { in soil past }\end{array}$} & \multicolumn{4}{|c|}{ Soluble Cations } & \multicolumn{3}{|c|}{ Soluble Anions } \\
\hline & & & $\mathrm{Ca}^{+2}$ & $\mathrm{Mg}^{+2}$ & $\mathrm{Na}^{+}$ & $\mathrm{K}^{+}$ & $\mathrm{HCO}_{3}^{-}$ & $\mathrm{Cl}^{-}$ & $\mathrm{SO}_{4}^{-2}$ \\
\hline $1^{\text {st }}$ & 8.05 & 9.45 & 8.92 & 14.33 & 70.38 & 0.87 & 7.30 & 60.00 & 27.20 \\
\hline $2^{\text {nd }}$ & 8.03 & 7.29 & 12.55 & 17.93 & 41.35 & 0.89 & 5.91 & 32.90 & 34.09 \\
\hline \multicolumn{4}{|c|}{ Available macronutrients } & \multicolumn{3}{|c|}{ Available micronutrients } & & & \\
\hline & $\mathrm{N}$ & $\mathrm{P}$ & $\mathrm{K}$ & $\mathrm{Fe}$ & & & $\mathrm{Mn}$ & $\mathrm{Zn}$ & \\
\hline $1^{\text {st }}$ & 36.71 & 4.40 & 193 & 3.73 & & & 2.40 & 0.67 & \\
\hline $2^{\text {nd }}$ & 39.97 & 4.78 & 197 & 3.88 & & & 2.46 & 0.72 & \\
\hline
\end{tabular}

All experimental plots were irrigated by ElSalam Canal (Agriculture drainage mixed with Nile water by rate 1:1). Samples of irrigation water were taken in November, January and February for chemical and macro- micronutrients analyses were according to Page $\boldsymbol{e t}$ al, (1982). The mean values of irrigation water analysis average of the two seasons are presented in Table (2).

Table 2. Mean values of chemical and macr- micronutraties of irrigation water used (over two seasons).

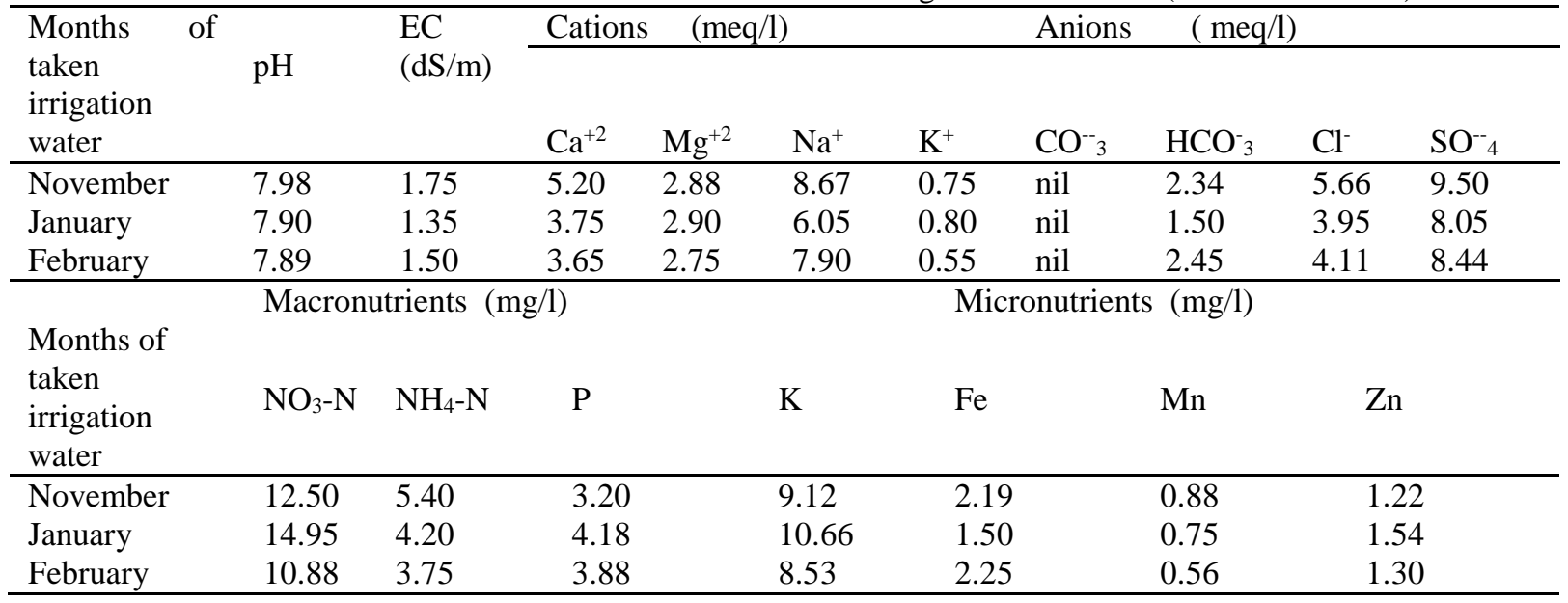

The experimental design was split plot with four replications. The local variety (Fahl) was used. Seeds were broadcasted at the rate of $20 \mathrm{~kg} \mathrm{fad}^{-1}$. Sowing date was $25^{\text {th }}$ October in the two seasons. The main plots represented three irrigation intervals were applied after the first irrigation (in the same day of planting).

The number of irrigation times at the three irrigation intervals were as follows:

- 12 days (nine numbers of irrigation times).

- 16 days (six numbers of irrigation times).

- 20 days (five numbers of irrigation times).

According to the recommended doses of water requirement of irrigation for clover variety fahl at Sahl EL- Hussinia region salinity soil $\left(2700 \mathrm{~m}^{3} / \mathrm{fad}\right)$ Ouda et al, (2015), it's distributed at number of irrigation times for every different treatments in order to salinity soil needs irrigation frequency to prevent hardening of surface layer and facilitate water continuously and calculate the amount of rain water to be subtracted from the amount of irrigation for every treatment.

The sub plots represented compost rates $(0,5$, 10 and 15 ton/fad). Compost was during soil tillage. The compost analysis was done according to the standard methods as described by Brunner and Wasmer (1978). Chemical composition of the used compost is shown in Table (4).

All farming processes were carried out before planting. Super phosphate $\left(15.5 \% \mathrm{P}_{2} \mathrm{O}_{5}\right)$ was applied at a rate of $100 \mathrm{~kg} \mathrm{fad}^{-1}$ during tillage soil. ammonium nitrate $(33.5 \% \mathrm{~N})$ at the rate of $20 \mathrm{~kg} / \mathrm{fad}$ was applied on three times 21, 45 and 65 days after planting. Potassium sulphat $\left(48 \% \mathrm{~K}_{2} \mathrm{O}\right)$ was applied at rate of $75 \mathrm{~kg} \mathrm{~K}_{2} \mathrm{O} \mathrm{fad}^{-1}$ on two equal times 21 and 55 days after planting.

At harvesting after 110 dayes, samples of ten plants from each experimental plot $(3 \times 4 \mathrm{~m})$ were taken at random and the following measurements were recorded: 
- Plant height $(\mathrm{cm})$, stem diameter, no. of branches/ plant and leaves/ stem ratio.

- Fresh yield (plants of the plot were hand clipped and weighed in $\mathrm{kg} / \mathrm{plot}$ and

Calculated to ton $\mathrm{fad}^{-1}$ ).
- Dry yield (Samples of $100 \mathrm{gm}$ were dried at $75 \mathrm{c}^{\circ}$ to constant weight and dry matter percentages were estimated. The dry forage yield was calculated by Multiplying fresh forage yield with dry matter percentage).

Table 3. Meteorological data for Sahl EL- Hussinia region (average in two seasons).

\begin{tabular}{llllll}
\hline \multirow{2}{*}{ Month } & \multicolumn{5}{c}{ Average in two seasons } \\
\cline { 2 - 6 } & $\mathbf{T . m a x}\left({ }^{\mathbf{0}} \mathbf{C}\right)$ & T.min $\left({ }^{\mathbf{0}} \mathbf{C}\right)$ & $\begin{array}{l}\text { W.S. } \\
\left(\mathbf{m ~ s}^{-\mathbf{1}}\right)\end{array}$ & $\begin{array}{c}\mathbf{R . H} . \\
(\boldsymbol{\%})\end{array}$ & $\begin{array}{c}\text { R. F. } \\
(\mathbf{m m})\end{array}$ \\
\hline October & 35.0 & 19.8 & 3.6 & 73.1 & 0.0 \\
November & 32.2 & 17.8 & 3.5 & 72.2 & 0.0 \\
December & 26.1 & 14.7 & 3.0 & 65.5 & 100 \\
January & 20.4 & 10.9 & 3.0 & 67.7 & 100 \\
February & 18.3 & 8.5 & 4.0 & 68.0 & 200 \\
\hline
\end{tabular}

Table 4. Chemical analysis of compost used.

\begin{tabular}{llllllllll}
\hline \multirow{2}{*}{$\begin{array}{l}\text { Moisture } \\
(\%)\end{array}$} & $\mathrm{pH}$ & $\mathrm{EC}(\mathrm{dSm}-$ & $\mathrm{C} / \mathrm{N}$ & $\mathrm{N}$ & $\mathrm{P}$ & $\mathrm{K}$ & $\mathrm{Fe}$ & $\mathrm{Mn}$ & $\mathrm{Zn}$ \\
\cline { 5 - 10 } & $(1: 2.5)$ & $1) 1: 10$ & $(\%)$ & & & & \multicolumn{2}{l}{$\begin{array}{l}\text { Available micronutrients } \\
\text { (mg kg-1) }\end{array}$} \\
\hline $\mathbf{2 5 - 2 7}$ & $\mathbf{7 . 4 9}$ & $\mathbf{3 . 1 5}$ & $\mathbf{2 1 . 5 8}$ & $\mathbf{2 . 2 2}$ & $\mathbf{0 . 8 4}$ & $\mathbf{2 . 6 9}$ & $\mathbf{8 7 . 3 6}$ & $\mathbf{6 0 . 1 4}$ & $\mathbf{3 5 . 1 0}$ \\
\hline
\end{tabular}

\section{Chemical analysis:}

The plant samples were collected from each sub plot, weighed and oven dried at $70^{\circ} \mathrm{C}$ for $48 \mathrm{hs}$ up to the constant weight, ground and prepared for digestion as described by Page $\boldsymbol{e t}$ al, (1982). A $0.5 \mathrm{~g}$ of each oven dried ground plant sample was digested using $\mathrm{H}_{2} \mathrm{SO}_{4}, \mathrm{HCLO}_{4}$ mixture according to the method described by Chapman and Pratt (1961).

- N by semi micro Kjeldahl, $\mathrm{P}$ by spectrophotometer using stannous chloride reagent,

$\mathrm{K}$ by the Flame photometer.

- Fe, Mn and $\mathrm{Zn}$ micronutrients were determined in plant digestion using the methods

Described by Page et al, (1982).

- Total carbohydrates \%, fiber were determined in the dry matter of plants, using the method described by Dubois et al, (1956).

- Protien percentage of plant was calculated by multiplying the nitrogen (\%) by the

factor 6.25 Hymowitz et al, (1972).

- proline concentration was determined from standard curve and calculated

using formula that presented by Bates et al, (1973).

\section{Statistical analysis:}

All data were statistically analyzed by the analysis of variance method according to Snedcor and Cochran (1989). Differences among means were tested by L.S.D. at 0.05 level of significance .Bartlett's test was done to test the homogeneity of error variance. The test was not significant for all assessed traits, so, the two season's data were combined.

\section{Results and Discussion}

A. Growth traits:

\section{Effect of irrigation intervals:}

Data in Table (5) showed that the treatments intervals irrigation at 12 days showed significant superiority over the other irrigation intervals and gave the highest values of plant height, stem diameter, no. of branches and leaves/ stem ratio compared with the other irrigation periods. On the other hand, irrigation at 20 days was significantly inferior and gave the lowest values of studied growth traits.

These results revealed that the frequent irrigation at 12- day is require in case of clay saline soil that would reduce salts from the surface layer of the soil or the layer of root zone. Thus better irrigation management practices are required that would reduce soil salinity and increase growth parameters and yield of plants. The present results revealed clearly that irrigation every 12 and 16 days supplied sufficient soil moisture in fahl root zone which increase the capacity of fahl clover plants in photosynthesis and consequently increased plant height, stem diameter, no. of branches and leaves stem ratio. These results are in agreement with those reported by El-Noemani et al, (2015) who found that plant height and no. of branches were increased by increasing water application level. El-Dakroury (2008) showed that increasing the irrigation treatments from 60 to $100 \%$ of $\mathrm{ET}_{0}$ (Evapotranspiration), significantly increased the growth criteria, i.e., plant height, number of branches, leaves/ stem ratio, dry weight of both stem and total plant. 
Table 5. Effect of irrigation intervals and compost rates on growth traits of fahl clover plants.

\begin{tabular}{|c|c|c|c|c|c|c|c|c|c|c|c|c|}
\hline \multirow[b]{2}{*}{ Treatments } & \multicolumn{3}{|c|}{ Plant height $(\mathrm{cm})$} & \multicolumn{3}{|c|}{ Stem diameter $(\mathrm{cm})$} & \multicolumn{3}{|c|}{$\begin{array}{l}\text { No. branches } \\
\text { plant }^{-1}\end{array}$} & \multicolumn{3}{|c|}{$\begin{array}{l}\text { Leaves / stem } \\
\text { ratio }\end{array}$} \\
\hline & $\begin{array}{l}2014 / \\
2015\end{array}$ & $\begin{array}{l}2015 / \\
2016\end{array}$ & Comb. & $\begin{array}{l}2014 / \\
2015\end{array}$ & $\begin{array}{l}2015 / \\
2016\end{array}$ & Comb & $\begin{array}{l}2014 / \\
2015\end{array}$ & $\begin{array}{l}2015 / \\
2016\end{array}$ & Comb. & $\begin{array}{l}2014 / \\
2015\end{array}$ & $\begin{array}{l}2015 / \\
2016\end{array}$ & Comb. \\
\hline \multicolumn{13}{|c|}{ Irrigation intervals } \\
\hline 12 days $\left(\mathrm{I}_{1}\right)$ & 101.5 & 107.2 & 104.4 & 0.44 & 0.46 & 0.45 & 6.68 & 7.44 & 7.06 & 0.76 & 0.83 & 0.80 \\
\hline 16 days $\left(\mathrm{I}_{2}\right)$ & 80.99 & 85.53 & 83.26 & 0.41 & 0.43 & 0.42 & 6.56 & 7.33 & 6.95 & 0.58 & 0.64 & 0.61 \\
\hline 20 days $\left(\mathrm{I}_{3}\right)$ & 77.91 & 82.23 & 80.07 & 0.37 & 0.38 & 0.38 & 6.31 & 7.18 & 6.75 & 0.57 & 0.62 & 0.59 \\
\hline L.S.D 0.05 & 2.05 & 2.20 & 1.96 & 0.03 & 0.03 & 0.02 & 0.15 & 0.07 & 0.18 & 0.04 & 0.03 & 0.02 \\
\hline \multicolumn{13}{|c|}{ Compost rates } \\
\hline$(0) \mathrm{T}_{1}$ & 77.2 & 80.81 & 79.01 & 0.37 & 0.38 & 0.38 & 6.34 & 7.26 & 6.80 & 0.58 & 0.64 & 0.61 \\
\hline$(5) \mathrm{T}_{2}$ & 82.4 & 88.61 & 85.51 & 0.39 & 0.41 & 0.40 & 6.41 & 7.30 & 6.95 & 0.64 & 0.71 & 0.68 \\
\hline$(10) \mathrm{T}_{3}$ & 91.31 & 95.01 & 93.16 & 0.42 & 0.44 & 0.43 & 6.89 & 7.34 & 6.96 & 0.69 & 0.75 & 0.72 \\
\hline$(15) \mathrm{T} 4$ & 96.36 & 102.1 & 99.25 & 0.44 & 0.47 & 0.46 & 6.73 & 7.38 & 7.06 & 0.75 & 0.83 & 0.79 \\
\hline L.S.D 0.05 & 1.94 & 2.01 & 1.98 & 0.04 & 0.04 & 0.03 & 0.16 & 0.09 & 0.12 & 0.05 & 0.03 & 0.03 \\
\hline \multicolumn{13}{|l|}{ Interaction } \\
\hline $\mathrm{I}_{1} \mathrm{X} \mathrm{T}_{1}$ & 85.01 & 89.11 & 87.06 & 0.39 & 0.40 & 0.39 & 6.43 & 7.39 & 6.91 & 0.60 & 0.68 & 0.64 \\
\hline $\mathrm{I}_{1} \mathrm{X} \mathrm{T}_{2}$ & 95.20 & 102.8 & 99.00 & 0.43 & 0.44 & 0.43 & 6.51 & 7.41 & 6.96 & 0.75 & 0.79 & 0.77 \\
\hline $\mathrm{I}_{1} \mathrm{X} \mathrm{T}_{3}$ & 110.6 & 116.2 & 113.4 & 0.46 & 0.48 & 0.47 & 6.80 & 7.46 & 7.13 & 0.80 & 0.85 & 0.83 \\
\hline $\mathrm{I}_{1} \mathrm{XT}_{4}$ & 115.4 & 120.5 & 117.9 & 0.49 & 0.53 & 0.51 & 6.96 & 7.50 & 7.23 & 0.92 & 0.98 & 0.95 \\
\hline $\mathrm{I}_{2} \mathrm{XT}_{1}$ & 74.14 & 78.14 & 76.14 & 0.36 & 0.38 & 0.37 & 6.38 & 7.29 & 6.84 & 0.54 & 0.59 & 0.57 \\
\hline $\mathrm{I}_{2} \mathrm{X} \mathrm{T}_{2}$ & 77.52 & 82.90 & 80.21 & 0.38 & 0.41 & 0.39 & 6.40 & 7.31 & 6.86 & 0.58 & 0.65 & 0.62 \\
\hline $\mathrm{I}_{2} \mathrm{X} \mathrm{T}_{3}$ & 83.12 & 85.41 & 84.26 & 0.43 & 0.44 & 0.43 & 6.62 & 7.36 & 6.99 & 0.59 & 0.64 & 0.62 \\
\hline $\mathrm{I}_{2} \mathrm{X} \mathrm{T}_{4}$ & 89.20 & 95.70 & 92.45 & 0.45 & 0.47 & 0.46 & 6.84 & 7.39 & 7.12 & 0.62 & 0.69 & 0.66 \\
\hline $\mathrm{I}_{3} \mathrm{X} \mathrm{T}_{1}$ & 72.45 & 75.18 & 73.82 & 0.33 & 0.35 & 0.34 & 6.20 & 7.11 & 6.66 & 0.50 & 0.54 & 0.65 \\
\hline $\mathrm{I}_{3} \mathrm{X} \mathrm{T}_{2}$ & 74.5 & 80.14 & 77.32 & 0.35 & 0.37 & 0.36 & 6.33 & 7.16 & 6.75 & 0.55 & 0.58 & 0.65 \\
\hline $\mathrm{I}_{3} \mathrm{X} \mathrm{T}_{3}$ & 80.20 & 83.42 & 81.81 & 0.37 & 0.39 & 0.38 & 6.35 & 7.19 & 6.77 & 0.60 & 0.65 & 0.72 \\
\hline $\mathrm{I}_{3} \mathrm{XT}_{4}$ & 84.50 & 90.20 & 87.3 & 0.38 & 0.40 & 0.39 & 6.39 & 7.25 & 6.82 & 0.66 & 0.71 & 0.76 \\
\hline L.S.D 0.05 & 3.05 & 2.20 & 1.92 & 0.04 & 0.05 & 0.02 & 0.05 & 0.03 & 0.04 & 0.03 & 0.02 & 0.04 \\
\hline
\end{tabular}

\section{Effect of compost rates:}

Data presented in Table (5) showed that the use of compost at rates $0,5,10$ and 15 ton/fad led to significant increases in plant height, stem diameter, no. of branches and leaves stem ratio in both seasons.

The highest increases of the previous growth traits were obtained by using compost at rate 15 ton/ fad in both seasons. These results could be explained by Ibrahim and Fadni (2013) findings, who indicated that the addition of organic fertilizer has an efficient amendment for improving the physical, chemical and nutritional properties of soil and increase crop parameters as well as yield. In other words addition of organic fertilizer led to decrease soil salinity and soil $\mathrm{pH}$ and increase the nutrients uptake.

\section{Effect of interaction:}

The interaction between compost rates and irrigation intervals on growth traits was significant. The interaction between irrigation at short interval 12 days and compost at rate 15 ton/fad gave the highest values of plant height, stem diameter, no. of branches and leaves stem ratio compared with other treatments. Results indicated clearly that the effect of compost on all studied traits was more pronounced with the 12 days irrigates interval that the other two intervals.

Roey and Jingjing (2015) found that the interaction between organic fertilizer at a rate 10 ton/ha and irrigation every 3 days caused reduction in all plants growth parameters compared with irrigation every 2 days.

\section{B. Fresh and dry yields (ton/ fad):}

Data in Table (6) presented the effect of irrigation intervals, compost rates and their interaction on fresh and dry yields of fahl clover.

\section{Effect of irrigation intervals:}

The effect of irrigation intervals and compost rates on fresh and dry forage yields of fahl plants was significant. Increasing compost rates and decreasing irrigation intervals increased significantly both fresh and dry forage yields. The relative decrease of mean combined values of fresh and dry yields were 11.56 and $27.21 \%$ and 21.31 and $36.06 \%$ for irrigation water intervals 16 and 20 days compared with irrigation intervals 12 days respectively, From these results the increases of fresh and dry yields /fad with the irrigation water (12 days), may be due to the roles of irrigation water applied at adequate quantity for different physiological processes, respiration, 
transpiration and activity of enzyme reaction. These results are in agreement by Mazher et al, (2012) who indicated that fresh and dry weights were gradually increased with decreasing irrigation water intervals.

Table 6. Effect of irrigation intervals and compost rates on fresh and dry yields in fahl clover plants.

\begin{tabular}{|c|c|c|c|c|c|c|}
\hline \multirow{2}{*}{ Treatments } & \multicolumn{3}{|c|}{ Fresh yield (ton/fad) } & \multicolumn{3}{|c|}{ Dry yield (ton/fad) } \\
\hline & $2014 / 2015$ & $2015 / 2016$ & Comb. & $2014 / 2015$ & $2015 / 2016$ & Comb. \\
\hline \multicolumn{7}{|c|}{ Irrigation intervals } \\
\hline 12 days $\left(\mathrm{I}_{1}\right)$ & 13.30 & 14.03 & 13.67 & 1.20 & 1.25 & 1.22 \\
\hline 16 days $\left(\mathrm{I}_{2}\right)$ & 11.52 & 12.67 & 12.09 & 0.94 & 0.99 & 0.96 \\
\hline 20 days $\left(\mathrm{I}_{3}\right)$ & 9.79 & 10.11 & 9.95 & 0.77 & 0.80 & 0.78 \\
\hline L.S.D 0.05 & 1.05 & 0.98 & 1.25 & 0.15 & 0.11 & 0.12 \\
\hline \multicolumn{7}{|c|}{ Compost rates } \\
\hline$(0$ rate $) \mathrm{T}_{1}$ & 8.84 & 9.33 & 9.09 & 0.73 & 0.76 & 0.75 \\
\hline$(5$ rate $) \mathrm{T}_{2}$ & 10.65 & 11.37 & 11.01 & 0.81 & 0.85 & 0.83 \\
\hline$(10$ rate $) \mathrm{T}_{3}$ & 13.04 & 13.75 & 13.39 & 1.08 & 1.13 & 1.11 \\
\hline$(15$ rate $) \mathrm{T}_{4}$ & 13.65 & 14.62 & 14.14 & 1.24 & 1.29 & 1.27 \\
\hline L.S.D 0.05 & 0.91 & 1.52 & 1.21 & 0.02 & 0.04 & 0.01 \\
\hline \multicolumn{7}{|l|}{ Interaction } \\
\hline $\mathrm{I}_{1} \mathrm{X} \mathrm{T}_{1}$ & 10.28 & 11.00 & 10.64 & 0.85 & 0.88 & 0.87 \\
\hline $\mathrm{I}_{1} \mathrm{X} \mathrm{T}_{2}$ & 12.88 & 13.44 & 13.16 & 0.95 & 0.98 & 0.97 \\
\hline $\mathrm{I}_{1} \mathrm{X} \mathrm{T}_{3}$ & 14.90 & 15.66 & 15.28 & 1.42 & 1.46 & 1.44 \\
\hline $\mathrm{I}_{1} \mathrm{XT}_{4}$ & 15.23 & 16.00 & 15.62 & 1.56 & 1.66 & 1.61 \\
\hline $\mathrm{I}_{2} \mathrm{XT}_{1}$ & 8.32 & 9.00 & 8.66 & 0.70 & 0.72 & 0.71 \\
\hline $\mathrm{I}_{2} \mathrm{X} \mathrm{T}_{2}$ & 10.20 & 11.55 & 10.87 & 0.79 & 0.88 & 0.84 \\
\hline $\mathrm{I}_{2} \mathrm{X} \mathrm{T}_{3}$ & 13.56 & 14.26 & 13.91 & 0.98 & 1.06 & 1.02 \\
\hline $\mathrm{I}_{2} \mathrm{X} \mathrm{T}_{4}$ & 14.00 & 15.87 & 14.94 & 1.27 & 1.29 & 1.28 \\
\hline $\mathrm{I}_{3} \mathrm{X} \mathrm{T}_{1}$ & 7.93 & 8.00 & 7.97 & 0.65 & 0.67 & 0.66 \\
\hline $\mathrm{I}_{3} \mathrm{X} \mathrm{T}_{2}$ & 8.88 & 9.12 & 9.00 & 0.68 & 0.70 & 0.69 \\
\hline $\mathrm{I}_{3} \mathrm{X} \mathrm{T}_{3}$ & 10.66 & 11.33 & 10.96 & 0.84 & 0.88 & 0.86 \\
\hline $\mathrm{I}_{3} \mathrm{XT}_{4}$ & 11.72 & 12.00 & 11.86 & 0.89 & 0.94 & 0.92 \\
\hline L.S.D 0.05 & 0.08 & 0.47 & 0.30 & 0.05 & 0.04 & 0.04 \\
\hline
\end{tabular}

\section{Effect of compost rates:}

Data in Table (6) revealed that both fresh and dry forage yields were significantly affected by compost rates. The highest values of fresh yield $14.62 \mathrm{ton} / \mathrm{fad}$ and dry yield 1.29 ton/fad were obtained by the highest rate of compost. This might be related to improvement in physical soil conditions which provide energy for microorganism activity and increase nutrients uptake which consequently led to increase fresh and dry yields Abbas et al, (2013). The relative increase of the combined values were 21.21, 47.30 and $55.60 \%$ for fresh yield and 10.66, 48.00 and $69.33 \%$ for dry yield as affected by compost rates (5,10 and 15 ton/fad) respectively.

Rashad et al, (2011) reported that composts application to soil led to positive effect as it improved the soil properties ameliorated the plant growth and enhanced nutrient's uptake.

\section{Effect of interaction:}

Data presented in Table (6) show the interaction effect between irrigation intervals and compost rates were significant on fresh and dry yields. The highest values of fresh and dry yields were 15.62 and 1.61 (ton /fad) were obtained with irrigation every 12 days combined with 15 ton compost. The results showed that irrigation every 12 days combined with compost at different rates had the highest fresh and dry yields of fahl clover compared with irrigation every 16 or 20 days. Abass et al, (2013) found that the increase of interaction between compost and different irrigation water levels on the fresh and dry yields of clover plants were significant increase by increasing compost and irrigation water intervals.

\section{Chemical constituents:}

\section{C.1. Macronutraties}

Macronutraties in plants of fahl clover as affected by irrigation intervals and compost rates are presented in Table (7).

\section{Effect of irrigation intervals:}

Results in Table (7) showed the impact of irrigation intervals gave increase of macronutrient concentration in clover plant as decreased irrigation interval 12 days than 16 or 20 days. Clearly, the irrigation intervals from 12 and 16 days up to 20 days led to increase in $\mathrm{N}, \mathrm{P}$ and $\mathrm{K}$ concentration in clover plants. The irrigation interval every 12 days led to significantly increase and gave highest values 
of $\mathrm{N}, \mathrm{P}$ and $\mathrm{K}$ content in both seasons. Hussein and Mahmoud (2013) reported that the decrease of N, P and $\mathrm{K}$ concentrations in Egyptian clover plant as affected drought stress. Davis (2007) suggested that the drought reduces both nutrients uptake by the roots transport from the roots to the shoots, because of restricted transpiration rates and impaired active transport and membrane permeability. Macronutrient deficiencies are very common under salt stress because of high pH (Zhu et al, 2004).

\section{Effect of Compost rates:}

Compost rates affected significantly all traits as shown in Table (7) compared with control. Generally the obtained high in macronutrient concentration in fahl plants may be due to the decreased of soil $\mathrm{pH}$, soil salinity and the increase of the activity microorganisms caused by the action of compost. Mazher et al, (2012) reported that increasing compost application led to increase of $\mathrm{N}, \mathrm{P}$ and $\mathrm{K}$ concentration in plants, these results may be due to the highest mineralization rate due to increase microbial activity and reduction in soil $\mathrm{pH}$.

\section{Effect of interaction:}

Date in Table (7) showed that interaction between irrigation intervals and compost rates on $\mathrm{N}$, $\mathrm{P}$ and $\mathrm{K}$ concentration were significantly increase with decreased irrigation water interval 12 days and increasing rate of compost. The highest values of $\mathrm{N}$, $\mathrm{P}, \mathrm{K}$ concentration in fahl plants were recorded with irrigation 12 days combined with 15 ton/fad compared with other treatments. These results are in agreement by Mazher et al, (2012) who indicated that $\mathrm{N}, \mathrm{P}$ and $\mathrm{K}$ content in plants were increased the interaction between application of Nile compost and irrigation intervals. Rashad et al, (2011) found that the increasing compost application rate gave enhanced nutrients uptake.

Table 7. Effect of irrigation intervals and compost on macronutrients concentration in clover fahl plants.

\begin{tabular}{|c|c|c|c|c|c|c|c|c|c|}
\hline \multirow[b]{2}{*}{ Treatments } & \multicolumn{3}{|l|}{$\mathrm{N}(\%)$} & \multicolumn{3}{|l|}{$\mathrm{P}(\%)$} & \multicolumn{3}{|l|}{$\mathrm{K}(\%)$} \\
\hline & $\begin{array}{l}\text { First } \\
\text { season }\end{array}$ & $\begin{array}{l}\text { Second } \\
\text { season }\end{array}$ & Comb. & $\begin{array}{l}\text { First } \\
\text { season }\end{array}$ & $\begin{array}{l}\text { Second } \\
\text { season }\end{array}$ & Comb. & $\begin{array}{l}\text { First } \\
\text { season }\end{array}$ & $\begin{array}{l}\text { Second } \\
\text { season }\end{array}$ & Comb. \\
\hline \multicolumn{10}{|c|}{ Irrigation intervals } \\
\hline 12 days $\left(\mathrm{I}_{1}\right)$ & 3.05 & 3.28 & 3.17 & 0.55 & 0.57 & 0.56 & 2.67 & 2.74 & 2.71 \\
\hline 16 days $\left(I_{2}\right)$ & 2.96 & 3.12 & 3.04 & 0.50 & 0.52 & 0.51 & 2.58 & 2.64 & 2.61 \\
\hline 20 days $\left(\mathrm{I}_{3}\right)$ & 2.93 & 3.03 & 2.98 & 0.42 & 0.46 & 0.44 & 2.48 & 2.52 & 2.50 \\
\hline L.S.D 0.05 & 0.31 & 0.43 & 0.41 & 0.03 & 0.03 & 0.05 & 0.08 & 0.10 & 0.04 \\
\hline \multicolumn{10}{|c|}{ Compost rates } \\
\hline (0 rate) $\mathrm{T}_{1}$ & 2.89 & 2.99 & 2.94 & 0.42 & 0.44 & 0.43 & 2.46 & 2.49 & 2.48 \\
\hline (5 rate) $\mathrm{T}_{2}$ & 2.94 & 3.12 & 3.03 & 0.47 & 0.49 & 0.48 & 2.53 & 2.59 & 2.56 \\
\hline (10 rate) $\mathrm{T}_{3}$ & 3.02 & 3.18 & 3.10 & 0.52 & 0.55 & 0.54 & 2.60 & 2.66 & 2.63 \\
\hline$(15$ rate)T4 & 3.06 & 3.25 & 3.16 & 0.56 & 0.60 & 0.58 & 2.71 & 2.77 & 2.74 \\
\hline L.S.D 0.05 & 0.05 & 0.03 & 0.05 & 0.02 & 0.04 & 0.02 & 0.07 & 0.08 & 0.05 \\
\hline \multicolumn{10}{|l|}{ Interaction } \\
\hline $\mathrm{I}_{1} \mathrm{X} \mathrm{T}_{1}$ & 2.94 & 3.04 & 2.99 & 0.45 & 0.48 & 0.465 & 2.50 & 2.55 & 2.53 \\
\hline $\mathrm{I}_{1} \mathrm{X} \mathrm{T}_{2}$ & 2.99 & 3.24 & 3.12 & 0.53 & 0.55 & 0.54 & 2.58 & 2.65 & 2.62 \\
\hline $\mathrm{I}_{1} \mathrm{X} \mathrm{T}_{3}$ & 3.12 & 3.35 & 3.24 & 0.58 & 0.62 & 0.60 & 2.70 & 2.78 & 2.74 \\
\hline $\mathrm{I}_{1} \mathrm{XT}_{4}$ & 3.16 & 3.47 & 3.32 & 0.63 & 0.66 & 0.645 & 2.88 & 2.97 & 2.93 \\
\hline $\mathrm{I}_{2} \mathrm{XT}_{1}$ & 2.88 & 2.98 & 2.93 & 0.42 & 0.44 & 0.43 & 2.45 & 2.48 & 2.47 \\
\hline $\mathrm{I}_{2} \mathrm{X} \mathrm{T}_{2}$ & 2.95 & 3.12 & 3.04 & 0.47 & 0.49 & 0.48 & 2.55 & 2.62 & 2.59 \\
\hline $\mathrm{I}_{2} \mathrm{X} \mathrm{T}_{3}$ & 2.99 & 3.17 & 3.08 & 0.53 & 0.56 & 0.55 & 2.60 & 2.67 & 2.64 \\
\hline $\mathrm{I}_{2} \mathrm{X} \mathrm{T}_{4}$ & 3.04 & 3.19 & 3.12 & 0.58 & 0.61 & 0.59 & 2.73 & 2.77 & 2.75 \\
\hline $\mathrm{I}_{3} \mathrm{X} \mathrm{T}_{1}$ & 2.86 & 2.95 & 2.91 & 0.38 & 0.40 & 0.39 & 2.42 & 2.45 & 2.44 \\
\hline $\mathrm{I}_{3} \mathrm{X} \mathrm{T}_{2}$ & 2.90 & 3.01 & 2.96 & 0.40 & 0.43 & 0.42 & 2.47 & 2.50 & 2.49 \\
\hline $\mathrm{I}_{3} \mathrm{X} \mathrm{T}_{3}$ & 2.95 & 3.07 & 3.01 & 0.45 & 0.48 & 0.47 & 2.49 & 2.53 & 2.51 \\
\hline $\mathrm{I}_{3} \mathrm{XT}_{4}$ & 2.99 & 3.10 & 3.05 & 0.48 & 0.52 & 0.50 & 2.53 & 2.58 & 2.56 \\
\hline L.S.D 0.05 & 0.07 & 0.05 & 0.04 & 0.03 & 0.04 & 0.01 & 0.04 & 0.03 & 0.02 \\
\hline
\end{tabular}

\section{2. Carbohydrate, protein, proline and fiber: Effect of irrigation intervals:}

Carbohydrate $\%$, protein $\%$ and fiber $(\mathrm{kg} / \mathrm{fad})$ content in fahl clover plant were increase with decreasing irrigation water intervals, while the proline $(\mu \mathrm{g} / \mathrm{g})$ content in fahl plant increase with increasing irrigation intervals.

The highest values for carbohydrate $\%$, protein $\%$ and fiber $(\mathrm{kg} / \mathrm{fad})$ content obtained with irrigation water interval 12 days, while the proline increase with increasing irrigation water intervals 16 and 20 
days. The increase of proline content in fahl clover plants due to the accumulating of osmolytes that do not perturb enzyme functions so as to maintain continuous water absorption at the low soil water potential (Hammad et al, 2010).

Sallam et al (2014) who indicated that increases of irrigation water led to increase of protein and carbohydrate content. Al-Suhaibani (2009) found that the high crude protein and carbohydrate percentage decreased with low water. Ibrahim et al, (2015) found that the increase value of carbohydrate content in fahl clover plant with increasing irrigation water quantity. Also, the relative decreased of mean values combined with two seasons were 21.43 and $31.02 \%$ for fiber content in fahl plant as affected by irrigation water intervals 16 and 20 days compared with 12 days. Jiang et al, (2012) and Kuchenmeister et al (2013) reported that the decreased of fiber content in forage legumes reflected to decrease of hemicelluloses content under drought. Sasani et al, (2004) observed the effect of irrigation intervals on pearl millet had significant effects on total protein; carbohydrates and fiber biomass. Mazher et al, (2012) indicated that increased of irrigation intervals led to decreased for different physiological processes.

Table 8. Effect of irrigation intervals and compost on fahl Chemical constituents.

\begin{tabular}{|c|c|c|c|c|c|c|c|c|c|c|c|c|}
\hline \multirow[b]{2}{*}{ Treatments } & \multicolumn{3}{|c|}{ Carbohydrate $\%$} & \multicolumn{3}{|c|}{ Protein $\%$} & \multicolumn{3}{|c|}{ Proline ( $\mu \mathrm{g} / \mathrm{g}$ f.w.) } & \multicolumn{2}{|c|}{ Fiber $(\mathrm{kg} / \mathrm{fad})$} & \multirow[b]{2}{*}{ Comb. } \\
\hline & $\begin{array}{l}2014 / \\
2015\end{array}$ & $\begin{array}{l}2015 / \\
2016\end{array}$ & Comb. & $\begin{array}{l}2014 / \\
2015\end{array}$ & $\begin{array}{l}2015 / \\
2016\end{array}$ & Comb & $\begin{array}{l}2014 / \\
2015\end{array}$ & $\begin{array}{l}2015 / \\
2016\end{array}$ & Comb. & $\begin{array}{l}2014 / \\
2015\end{array}$ & $\begin{array}{l}2015 / \\
2016\end{array}$ & \\
\hline \multicolumn{13}{|c|}{ Irrigation intervals } \\
\hline 12 days $\left(\mathrm{I}_{1}\right)$ & 72.38 & 73.64 & 73.01 & 19.08 & 20.47 & 19.78 & 341 & 327 & 334 & 428.7 & 430.7 & 429.7 \\
\hline 16 days $\left(\mathrm{I}_{2}\right)$ & 68.10 & 68.78 & 68.44 & 18.53 & 19.47 & 19.00 & 371 & 356 & 363 & 334.2 & 340.9 & 337.6 \\
\hline 20 days $\left(\mathrm{I}_{3}\right)$ & 64.53 & 65.21 & 64.87 & 18.29 & 18.96 & 18.63 & 390 & 378 & 384 & 294.1 & 298.7 & 296.4 \\
\hline L.S.D 0.05 & 2.90 & 2.14 & 1.89 & 0.20 & 0.42 & 0.31 & 4.30 & 6.18 & 4.09 & 5.12 & 6.18 & 4.82 \\
\hline \multicolumn{13}{|c|}{ Compost rates } \\
\hline$(0$ rate $) \mathrm{T}_{1}$ & 61.81 & 62.43 & 62.12 & 18.09 & 18.69 & 18.39 & 558 & 552 & 555 & 273.7 & 284.7 & 279.2 \\
\hline$(5$ rate $) \mathrm{T}_{2}$ & 68.01 & 68.67 & 68.34 & 18.42 & 19.52 & 18.97 & 470 & 447 & 459 & 321.6 & 335.4 & 328.5 \\
\hline$(10$ rate $) \mathrm{T}_{3}$ & 70.81 & 71.81 & 71.31 & 18.88 & 19.98 & 19.43 & 257 & 245 & 251 & 376.5 & 376.1 & 376.3 \\
\hline$(15$ rate $) \mathrm{T} 4$ & 72.71 & 73.92 & 73.32 & 19.15 & 20.34 & 19.75 & 184 & 172 & 178 & 432.9 & 435.7 & 434.3 \\
\hline L.S.D 0.05 & 1.45 & 1.52 & 1.14 & 0.21 & 0.35 & 0.29 & 3.19 & 4.02 & 2.54 & 3.83 & 3.71 & 3.16 \\
\hline \multicolumn{13}{|l|}{ Interaction } \\
\hline $\mathrm{I}_{1} \mathrm{X} \mathrm{T}_{1}$ & 65.90 & 66.30 & 66.1 & 18.38 & 19.00 & 18.69 & 540 & 530 & 535 & 329.0 & 340.1 & 334.6 \\
\hline $\mathrm{I}_{1} \mathrm{X} \mathrm{T_{2 }}$ & 72.60 & 73.00 & 72.80 & 18.69 & 20.25 & 19.47 & 420 & 390 & 405 & 366.0 & 377.8 & 371.9 \\
\hline $\mathrm{I}_{1} \mathrm{X} \mathrm{T_{3 }}$ & 74.80 & 76.34 & 75.57 & 19.50 & 20.94 & 20.22 & 228 & 223 & 226 & 482.6 & 485.2 & 483.9 \\
\hline $\mathrm{I}_{1} \mathrm{XT}_{4}$ & 76.23 & 78.90 & 77.56 & 19.75 & 21.69 & 20.72 & 178 & 166 & 172 & 525.3 & 531.5 & 528.4 \\
\hline $\mathrm{I}_{2} \mathrm{XT}_{1}$ & 60.55 & 61.00 & 60.78 & 18.00 & 18.63 & 18.32 & 563 & 560 & 561 & 263.3 & 278.0 & 270.7 \\
\hline $\mathrm{I}_{2} \mathrm{X} \mathrm{T}_{2}$ & 68.30 & 69.00 & 68.65 & 18.44 & 19.50 & 18.97 & 480 & 460 & 470 & 333.0 & 300.0 & 316.5 \\
\hline $\mathrm{I}_{2} \mathrm{X} \mathrm{T}_{3}$ & 70.66 & 72.10 & 71.38 & 18.69 & 19.81 & 19.25 & 255 & 235 & 245 & 336.0 & 328.0 & 332.0 \\
\hline $\mathrm{I}_{2} \mathrm{X} \mathrm{T}_{4}$ & 72.90 & 73.00 & 72.95 & 19.00 & 19.94 & 19.47 & 185 & 170 & 178 & 431.6 & 430.7 & 431.2 \\
\hline $\mathrm{I}_{3} \mathrm{X} \mathrm{T}_{1}$ & 59.00 & 60.00 & 59.5 & 17.88 & 18.44 & 18.16 & 570 & 566 & 568 & 228.7 & 236.0 & 232.4 \\
\hline $\mathrm{I}_{3} \mathrm{X} \mathrm{T} \mathrm{T}_{2}$ & 63.12 & 64.00 & 63.56 & 18.13 & 18.81 & 18.47 & 510 & 490 & 500 & 295.3 & 298.8 & 297.1 \\
\hline $\mathrm{I}_{3} \mathrm{X} \mathrm{T}_{3}$ & 66.98 & 67.00 & 66.99 & 18.44 & 19.19 & 18.82 & 289 & 277 & 283 & 310.8 & 315.0 & 312.9 \\
\hline $\mathrm{I}_{3} \mathrm{XT}_{4}$ & 69.00 & 69.87 & 69.44 & 18.69 & 19.38 & 19.04 & 190 & 180 & 185 & 341.7 & 345.0 & 343.4 \\
\hline L.S.D 0.05 & 1.01 & 1.00 & 0.78 & 0.99 & 1.00 & 0.89 & 4.99 & 4.08 & 3.69 & 5.06 & 6.06 & 4.03 \\
\hline
\end{tabular}

\section{Effect of compost rates:}

Compost rates affected significantly all traits as shown in Table (8). Compost rates application led to increasing of protein $(\%)$, carbohydrate $(\%)$, and fiber $(\mathrm{kg} / \mathrm{fad})$ contents, while the decreased of proline ( $\mu \mathrm{g} / \mathrm{g}$ f.w.) content. The applied of compost led to increase of organic matter and the helps to increase the respiration role, the metabolism and increase carbohydrates, protein and fiber content accumulation, (Mazher et al, 2012). Turan et al, (2009) found that the proline accumulation in salt stressed plants is a primary defense response to maintain the osmotic pressure in a cell and its function in plants in salt tolerant and salt sensitive.

\section{Effect of interaction:}

Regarding the effect of interaction between the irrigation intervals and compost rates treatments was significant on carbohydrate $(\%)$, protein $(\%)$, proline $(\mu \mathrm{g} / \mathrm{g})$ and fiber $(\mathrm{kg} / \mathrm{fad})$. This significant effect means that the effect of compost was not the same under the three different water intervals. The highest values were obtained from compost rate of 15 ton/fad with 12 days of irrigation intervals. 
- Soil chemical properties:

Effect of irrigation intervals on soil PH:

Results in Table (9) showed that the soil $\mathrm{pH}$ decreased with decreasing irrigation water interval. The effect of irrigation water intervals on soil $\mathrm{pH}$ was significant in both seasons. The soil $\mathrm{pH}$ of all experimental plots is characterized by slightly to moderately alkaline conditions, where the average $\mathrm{pH}$ value was always around 8.00 to 7.93 , FAO (1992). This decrease soil $\mathrm{pH}$ value may be resulted from the oxidation of $\mathrm{NO}_{3}$ content in irrigation and soil led to increase produced of nitric acid. These is agreement by Hedia (2014) found that the increase the amount of applied water led to decreased of soil $\mathrm{pH}$ from 8.38 to 7.78 . Abd El-Naby et al, (2014) suggested that the alfalfa clover product the symbiotic $\mathrm{N}_{2}$ fixation acidified their rhizosphere, causing a considerable $\mathrm{H}^{+}$extrusion in the rhizosphere to decrease soil $\mathrm{pH}$.

\section{Effect of compost on soil pH.}

Results in Table (9) showed that the application of compost different rates on soil was decreased soil $\mathrm{pH}$ with increasing rate of compost applied. In generally, increasing compost rate of application led to decrease soil $\mathrm{pH}$ reflected to be due to the active of microorganism, biological activity in particular and organic produced. The mean value of soil $\mathrm{pH}$ in two seasons ranged between from (7.95 to 7.87). This may be due to added compost being mostly of activity by microorganisms and product of organic acids. Shaban $\boldsymbol{e t}$ al, (2011) found that the application of organic manure increase microbial activity in the soil, which may increases of the organic matter content due to the active microorganism, biological activity in particular and organic acid produced led to decrease of soil $\mathrm{pH}$.

\section{Effect of Interaction}

Data in table (9) showed that interaction between irrigation intervals and compost on soil $\mathrm{pH}$ values was significant effect. The results revealed that irrigation intervals every 12 days with combined compost by rate 20 ton /fad had the reduced of soil $\mathrm{pH}$ than other treatments. These results are in agreement by Abdullah (2007) found that increase of compost rate applied to saline soil led to improving the physical and chemical properties of soil and decreasing soil pH. Shaban et al, (2011) indicated that applied of compost due to the active microorganism, biological activity and organic acid produced led to decreased of soil $\mathrm{pH}$.

Table 9. Effect of irrigation water intervals and compost different rates on soil $\mathrm{pH}$ and soil EC $\left(\mathrm{dSm}^{-1}\right)$.

\begin{tabular}{|c|c|c|c|c|c|c|}
\hline \multirow[b]{2}{*}{ Treatments } & \multicolumn{2}{|c|}{$\mathrm{pH}(1: 2.5)$} & \multirow{2}{*}{ Comb. } & \multicolumn{2}{|c|}{$\mathrm{EC}\left(\mathrm{dSm}^{-1}\right)$} & \multirow{2}{*}{ Comb. } \\
\hline & $2014 / 2015$ & $2015 / 2016$ & & $2014 / 2015$ & $2015 / 2016$ & \\
\hline \multicolumn{7}{|c|}{ Irrigation intervals } \\
\hline 12 days $\left(\mathrm{I}_{1}\right)$ & 7.92 & 7.87 & 7.89 & 5.24 & 4.89 & 5.07 \\
\hline 16 days $\left(\mathrm{I}_{2}\right)$ & 7.94 & 7.91 & 7.93 & 6.06 & 5.47 & 5.77 \\
\hline 20 days $\left(I_{3}\right)$ & 7.98 & 7.94 & 7.96 & 6.34 & 5.68 & 6.01 \\
\hline L.S.D 0.05 & 0.03 & 0.02 & 0.02 & 0.05 & 0.03 & 0.02 \\
\hline \multicolumn{7}{|c|}{ Compost rates } \\
\hline$(0$ rate $) \mathrm{T}_{1}$ & 8.01 & 7.98 & 7.99 & 6.80 & 6.01 & 6.41 \\
\hline$(5$ rate $) \mathrm{T}_{2}$ & 7.97 & 7.93 & 7.95 & 6.05 & 5.70 & 5.88 \\
\hline$(10$ rate $) \mathrm{T}_{3}$ & 7.91 & 7.88 & 7.89 & 5.60 & 5.02 & 5.31 \\
\hline$(15$ rate $) \mathrm{T} 4$ & 7.89 & 7.84 & 7.87 & 5.06 & 4.64 & 4.85 \\
\hline LSD. 0.05 & 0.03 & 0.04 & 0.03 & 0.02 & 0.05 & 0.03 \\
\hline \multicolumn{7}{|l|}{ Interaction } \\
\hline $\mathrm{I}_{1} \mathrm{XT}_{1}$ & 7.98 & 7.95 & 7.97 & 6.48 & 5.88 & 6.18 \\
\hline $\mathrm{I}_{1} \mathrm{X} \mathrm{\textrm {T } _ { 2 }}$ & 7.95 & 7.89 & 7.92 & 5.41 & 5.44 & 5.43 \\
\hline $\mathrm{I}_{1} \mathrm{X} \mathrm{T_{3 }}$ & 7.88 & 7.85 & 7.87 & 4.93 & 4.35 & 4.64 \\
\hline $\mathrm{I}_{1} \mathrm{X} \mathrm{T}_{4}$ & 7.85 & 7.80 & 7.83 & 4.12 & 3.88 & 4.00 \\
\hline $\mathrm{I}_{2} \mathrm{XT}_{1}$ & 8.01 & 7.98 & 7.99 & 6.94 & 5.92 & 6.43 \\
\hline $\mathrm{I}_{2} \mathrm{X} \mathrm{T}_{2}$ & 7.97 & 7.93 & 7.95 & 6.18 & 5.77 & 5.98 \\
\hline $\mathrm{I}_{2} \mathrm{X} \mathrm{T}_{3}$ & 7.90 & 7.88 & 7.89 & 5.72 & 5.23 & 5.48 \\
\hline $\mathrm{I}_{2} \mathrm{X} \mathrm{T}_{4}$ & 7.88 & 7.84 & 7.86 & 5.39 & 4.95 & 5.17 \\
\hline $\mathrm{I}_{3} \mathrm{XT}_{1}$ & 8.03 & 8.00 & 8.02 & 6.98 & 6.23 & 6.61 \\
\hline $\mathrm{I}_{3} \mathrm{X} \mathrm{T}_{2}$ & 8.00 & 7.96 & 7.98 & 6.55 & 5.89 & 6.22 \\
\hline $\mathrm{I}_{3} \mathrm{X} \mathrm{T}_{3}$ & 7.96 & 7.92 & 7.94 & 6.15 & 5.49 & 5.82 \\
\hline $\mathrm{I}_{3} \mathrm{X} \mathrm{T}_{4}$ & 7.93 & 7.88 & 7.91 & 5.66 & 5.10 & 5.38 \\
\hline LSD. 0.05 & 0.04 & 0.02 & 0.03 & 0.03 & 0.02 & 0.01 \\
\hline
\end{tabular}


Generally the compost and irrigation intervals were significant decreased in soil $\mathrm{pH}$. The decrease of soil $\mathrm{pH}$ reflected to increase of compost rate to fahl clover planting is due to increase nitrogen fixation, increasing organic matter and activity of microorganisms in root zone due to produced organic acid. These results are in agreement by HosseinZadeh et al, (2008) stated that, $\mathrm{pH}$ decrease due to increased organic matter, organic and inorganic acids occurs, The most abundant acid is carbonic acid, although acid is a weak acid but it permanent production in soil where root density is high makes dissolve lime in the soil and get out of the soil $\mathrm{pH}$ is reduced, under alfalfa planting Ramezan et al, (2013).

\section{Effect of irrigation intervals on EC:}

Data in Table (9) showed that the total soluble salts in soil study as affected by irrigation intervals were decrease with increasing the irrigation periods. This finding is in agreement with that obtained by Shaban (2005) reported that using water from ElSalam Canal led to decrease of soil salinity by salts leached out from the soil tented to increase by increasing period irrigation water. This decrease can allow the increase of soil porosity and consequently, the improvement of irrigation water leaching. The minimum of mean value of EC soil was $5.07 \mathrm{dSm}^{-1}$ in the soil treated after 12 days, than other irrigation intervals (16 and 20 days). The increase irrigation periods (16 and 20 days) imposed a more rapid salt accumulation in the root zone, which was ascribed to restriction of the volume of drainage solution.

\section{Effect of compost on EC:}

From these data in Table (9), it observed that the total soluble salts decreased as a result of using compost at a rates 20 ton /fad followed by 5 and 10 ton /fad. The EC of soil was slightly enhanced by application compost. These findings are in harmony with those indicated by Wang et al, (2014) found that a mixture of compost decreased bulk density, $\mathrm{EC}$, and increased total porosity and organic carbon respectively, than the control.

\section{Effect of interaction:}

Effect of interaction between irrigation water intervals and compost rates on total soluble salts was decrease by increasing irrigation water periods and high rate of compost. The application compost at different rates led to increase of microorganism's activity, total porosity, and improves soil aggregation and possible leaching salt soil under increase periods of irrigation water. These results are in agreement by Mariangela and Francesco (2015) found that the effect of organic fertilizers application on saline soil was improving chemical, physical soil properties and soil remediation in salt affected soil due to their high organic matter content and active biological. This may be due to the positive effect of released active organic acids which enhancing soil aggregation and created conductive prose which led to the excess remove of soluble salts, Abdullah (2007).

Macro-micronutrients in soil study after fahl clover harvest.

\section{Effect of irrigation intervals:}

Macronutrients, i.e. ( $\mathrm{N}, \mathrm{P}$ and $\mathrm{K}$ ) available in soil after fahl clover plants over in both seasons were significantly affected by irrigation intervals while the micronutrients availability (Fe, $\mathrm{Mn}$ and $\mathrm{Zn}$ ) content in soil were no significant affect. Data in Tables (10, 11) showed the irrigation every 12 days led to increasing available of macro-micronutrients in soil. The decreased of macro- micronutrients availability in soil due to increasing the irrigation intervals from 16 to 20 days respectively. Hu et al, (2007) indicated that the drought cause low nutrient availability in soil.

\section{Effect of compost:}

Data in Tables $(10 \& 11)$ showed that the effect of compost rates applied to soil after fahl clover harvest on macronutrients $(\mathrm{N}, \mathrm{P}$ and $\mathrm{K})$ was significant increase with increasing rate, while the micronutrients ( $\mathrm{Fe}, \mathrm{Mn}$ and $\mathrm{Zn}$ ) available content was no significant. The highest mean values of $\mathrm{N}, \mathrm{P}$, $\mathrm{K}, \mathrm{Fe}, \mathrm{Mn}$ and $\mathrm{Zn}$ for soil treated with high rate from compost 15 ton/fad compared with 0,5 and 10 ton /fad. The relative increase of mean combined two season's values $6.64,9.75$ and $12.35 \%$ for $\mathrm{N} ; 3.70$, 16.66 and $19.55 \%$ for $\mathrm{P}$ and $2.88,8.18$ and $14.24 \%$ for $\mathrm{K}$ availability content in soil as affected by compost at a rates 5, 10 and 15 ton/fad respectively compared with soil treated by 0 ton/fed compost. On the other hand, the relative increase of mean combined two seasons values were 2.07, 3.88 and $5.69 \%$ for $\mathrm{Fe} ; 5.86,10.16$ and 12.50 for $\mathrm{Mn}$ and $16.66,22.22$ and $29.16 \%$ for $\mathrm{Zn}$ available in soil treated with compost applied at a rates 5, 10 and 15 ton/fad respectively compared control. Also, may be due to the effect of high rate of compost applied to soil reflect to release organic acids, organic substance, enhance soil microbial activity of soil, such as improving activity of soil enzymes and increasing soil microbial biomass leading a reduction in soil $\mathrm{pH}$ values and consequently increasing macro-micronutrients available content in soil.

Generally, the results are suggested that the applied the high rates of compost resulted in a increase of $\mathrm{N}, \mathrm{P}, \mathrm{K}, \mathrm{Fe}, \mathrm{Mn}$ and $\mathrm{Zn}$ content in soil. This result may be due to imbalance of nutrients, release of organic acids, organic substances and macro-micronutrients release from compost during decomposition of compost led to decrease soil $\mathrm{pH}$ reflected to increase available macro-micronutrients content in soil. He and $\mathbf{L i}$ (2004) indicated that the application of organic combined with inorganic 
fertilizers led to increase the activities of available nutrient content in soil.

\section{Effect of Interaction:}

Data in Table $(10,11)$ showed that pronounced increase in soil available macromicronutrients content i.e. $\mathrm{N}, \mathrm{P}, \mathrm{K} \mathrm{Fe}, \mathrm{Mn}$ and $\mathrm{Zn}$ were achieved as a result of irrigation water intervals 12 and 16 days under applied compost at rates 10 and 15 ton/fad compared with other treatments. This is more related to the residual organic compounds that directly compost led to release more available macromicronutrients. In addition, the relative increases of these macro-micronutrients in the soil after fahl clover harvest as affected by high rate of compost (15 ton/fad) and decrease irrigation water interval (12 days) compared with other treatments. From the aforementioned results, it could be concluded that N, $\mathrm{P}, \mathrm{K}, \mathrm{Fe}, \mathrm{Mn}$ and $\mathrm{Zn}$ tend to increase in the studied soils with increasing irrigation period and compost rate. Also, the effect of interaction between irrigation intervals and different rates of compost on macromicronutrients available in soil was significant increase with decreasing irrigation water interval and increase of rate of compost.

This is due to deceasing in both soil $\mathrm{pH}$ and soil salinity. These increases of macro-micronutrients reflect to the accumulation of organic collides and activity of microorganisms led to an increase of available water dissolved organic carbon and a decreased soil $\mathrm{pH}$ value and increase of nutrients mobility and bio-availability. Ibrahim et al, (2015) indicated that the increase irrigation water rate led to increase of available $\mathrm{N}, \mathrm{P}, \mathrm{K}, \mathrm{Fe}, \mathrm{Mn}$ and $\mathrm{Zn}$ in saline soil during fahl clover cultivate. The available of $\mathrm{N}, \mathrm{P}, \mathrm{K}, \mathrm{Fe}, \mathrm{Mn}$ and $\mathrm{Zn}$ content in soil studied depended on the reduced of soil $\mathrm{pH}$ as well as the nature of binding's sites on organic and inorganic particle surface.

Table 10. Effect of irrigation water intervals and compost rates on macronutrients available content in soil.

\begin{tabular}{|c|c|c|c|c|c|c|c|c|c|}
\hline \multirow[b]{2}{*}{ Treatments } & \multicolumn{3}{|l|}{$\mathbf{N} \%$} & \multicolumn{3}{|l|}{$\mathbf{P \%}$} & \multicolumn{3}{|l|}{$\mathbf{K} \%$} \\
\hline & $\begin{array}{l}2014 / \\
2015 \\
\end{array}$ & $\begin{array}{l}2015 / \\
2016 \\
\end{array}$ & Comb. & $\begin{array}{l}2014 / \\
2015 \\
\end{array}$ & $\begin{array}{l}2015 / \\
2016\end{array}$ & Comb. & $\begin{array}{l}2014 / \\
2015\end{array}$ & $\begin{array}{l}2015 / \\
2016\end{array}$ & Comb. \\
\hline \multicolumn{10}{|c|}{ Irrigation intervals } \\
\hline 12 days $\left(I_{1}\right)$ & 42.68 & 43.63 & 43.16 & 5.76 & 5.95 & 5.86 & 221.5 & 227.5 & 224.5 \\
\hline 16 days $\left(I_{2}\right)$ & 41.80 & 42.08 & 41.94 & 5.08 & 5.45 & 5.27 & 203 & 210.3 & 206.7 \\
\hline 20 days $\left(I_{3}\right)$ & 40.97 & 41.39 & 41.18 & 4.83 & 5.00 & 4.92 & 198.8 & 202.5 & 200.7 \\
\hline L.S.D 0.05 & 0.59 & 0.61 & 0.45 & 0.13 & 0.18 & 0.11 & 3.25 & 3.52 & 3.15 \\
\hline \multicolumn{10}{|c|}{ Compost rates } \\
\hline (0 rate) $T_{1}$ & 38.29 & 40.25 & 39.27 & 4.79 & 4.93 & 4.86 & 196.0 & 200.0 & 198.0 \\
\hline (5 rate) $T_{2}$ & 41.72 & 42.04 & 41.88 & 4.95 & 5.13 & 5.04 & 200.1 & 207.3 & 203.7 \\
\hline$(10$ rate $) T_{3}$ & 43.12 & 43.07 & 43.10 & 5.50 & 5.84 & 5.67 & 210.6 & 217.7 & 214.2 \\
\hline (15 rate)T4 & 44.14 & 44.10 & 44.12 & 5.65 & 5.97 & 5.81 & 223.7 & 228.7 & 226.2 \\
\hline LSD.0.05 & 1.90 & 1.50 & 1.24 & 0.12 & 0.18 & 0.09 & 3.14 & 4.10 & 3.20 \\
\hline \multicolumn{10}{|l|}{ Interaction } \\
\hline $\mathrm{I}_{1} \mathrm{XT}_{1}$ & 38.62 & 40.52 & 39.57 & 4.99 & 5.06 & 5.03 & 198 & 203 & 200.5 \\
\hline $\mathbf{I}_{1} \mathbf{X} \mathbf{T}_{2}$ & 42.18 & 42.89 & 42.54 & 5.20 & 5.44 & 5.32 & 205 & 213 & 209.0 \\
\hline $\mathbf{I}_{1} \mathbf{X} \mathbf{T}_{3}$ & 44.69 & 44.89 & 44.79 & 6.38 & 6.59 & 6.49 & 229 & 234 & 231.5 \\
\hline $\mathbf{I}_{1} \mathbf{X} \mathbf{T}_{4}$ & 45.23 & 46.20 & 45.72 & 6.45 & 6.70 & 6.58 & 254 & 260 & 257.0 \\
\hline $\mathbf{I}_{2} \mathbf{X T}_{1}$ & 38.24 & 40.22 & 39.23 & 4.78 & 4.98 & 4.88 & 196 & 199 & 197.5 \\
\hline $\mathbf{I}_{2} \mathbf{X} \mathbf{T}_{2}$ & 41.65 & 41.77 & 41.71 & 4.98 & 5.04 & 5.01 & 199 & 208 & 203.5 \\
\hline $\mathbf{I}_{2} \mathbf{X} \mathbf{T}_{3}$ & 42.80 & 42.36 & 42.58 & 5.23 & 5.84 & 5.54 & 203 & 215 & 209 \\
\hline $\mathbf{I}_{2} \mathbf{X} \mathbf{T}_{4}$ & 44.52 & 43.96 & 44.24 & 5.34 & 5.95 & 5.65 & 214 & 219 & 216.5 \\
\hline $\mathbf{I}_{3} \mathbf{X T}_{1}$ & 38.00 & 41.00 & 39.5 & 4.59 & 4.75 & 4.67 & 194 & 198 & 196 \\
\hline $\mathbf{I}_{3} \mathbf{X} \mathbf{T}_{2}$ & 41.33 & 41.45 & 41.39 & 4.68 & 4.90 & 4.79 & 198 & 201 & 199.5 \\
\hline $\mathbf{I}_{\mathbf{3}} \mathbf{X} \mathbf{T}_{\mathbf{3}}$ & 41.88 & 41.96 & 41.92 & 4.89 & 5.10 & 4.99 & 200 & 204 & 202 \\
\hline $\mathbf{I}_{3} \mathbf{X} \mathbf{T}_{4}$ & 42.67 & 42.15 & 42.41 & 5.15 & 5.26 & 5.21 & 203 & 207 & 205 \\
\hline LSD. 0.05 & 0.56 & 0.71 & 0.55 & 0.13 & 0.12 & 0.10 & 3.89 & 3.59 & 3.14 \\
\hline
\end{tabular}


Table 11. Effect of irrigation intervals and compost rates on micronutrients available content in soil

\begin{tabular}{|c|c|c|c|c|c|c|c|c|c|}
\hline \multirow[b]{2}{*}{ Treatments } & \multicolumn{3}{|c|}{$\mathrm{Fe}(\mathrm{mg} / \mathrm{kg})$} & \multicolumn{3}{|c|}{ Mn (mg/kg) } & \multicolumn{3}{|c|}{ Zn(mg/kg) } \\
\hline & $\begin{array}{l}2014 / \\
2015\end{array}$ & $\begin{array}{l}2015 / \\
2016\end{array}$ & Comb. & $\begin{array}{l}2014 / \\
2015\end{array}$ & $\begin{array}{l}2015 / \\
2016\end{array}$ & Comb & $\begin{array}{l}2014 / \\
2015\end{array}$ & $\begin{array}{l}2015 / \\
2016\end{array}$ & Comb. \\
\hline \multicolumn{10}{|c|}{ Irrigation intervals } \\
\hline 12 days $\left(I_{1}\right)$ & 3.99 & 4.11 & 4.05 & 2.79 & 2.91 & 2.85 & 0.85 & 0.89 & 0.87 \\
\hline 16 days $\left(I_{2}\right)$ & 3.91 & 4.02 & 3.97 & 2.71 & 2.76 & 2.74 & 0.82 & 0.86 & 0.84 \\
\hline 20 days $\left(I_{3}\right)$ & 3.81 & 3.99 & 3.90 & 2.64 & 2.65 & 2.65 & 0.80 & 0.83 & 0.82 \\
\hline L.S.D 0.05 & N.s & N.s & N.s & N.s & N.s & N.s & N.s & N.s & N.s \\
\hline \multicolumn{10}{|c|}{ Compost rates } \\
\hline$(0$ rate $) T_{1}$ & 3.78 & 3.94 & 3.86 & 2.51 & 2.61 & 2.56 & 0.69 & 0.74 & 0.72 \\
\hline (5 rate) $\mathrm{T}_{2}$ & 3.87 & 4.01 & 3.94 & 2.67 & 2.75 & 2.71 & 0.82 & 0.85 & 0.84 \\
\hline (10 rate) $T_{3}$ & 3.94 & 4.08 & 4.01 & 2.80 & 2.84 & 2.82 & 0.86 & 0.90 & 0.88 \\
\hline (15 rate)T4 & 4.02 & 4.13 & 4.08 & 2.87 & 2.89 & 2.88 & 0.91 & 0.94 & 0.93 \\
\hline L.S.D 0.05 & N.s & N.s & N.s & N.s & N.s & N.s & N.s & N.s & N.s \\
\hline \multicolumn{10}{|l|}{ Interaction } \\
\hline $\mathbf{I}_{1} \mathbf{X} \mathbf{T}_{1}$ & 3.80 & 3.97 & 3.89 & 2.55 & 2.75 & 2.65 & 0.72 & 0.75 & 0.74 \\
\hline $\mathrm{I}_{1} \mathrm{X} \mathrm{T}_{2}$ & 3.97 & 4.07 & 4.02 & 2.75 & 2.88 & 2.81 & 0.84 & 0.87 & 0.86 \\
\hline$I_{1} X T_{3}$ & 4.04 & 4.17 & 4.11 & 2.89 & 2.97 & 2.93 & 0.89 & 0.95 & 0.92 \\
\hline $\mathrm{I}_{\mathbf{1}} \mathbf{X T}_{4}$ & 4.13 & 4.24 & 4.19 & 2.99 & 3.02 & 3.01 & 0.94 & 0.98 & 0.96 \\
\hline $\mathbf{I}_{2} \mathbf{X} \mathbf{T}_{1}$ & 3.78 & 3.95 & 3.87 & 2.50 & 2.55 & 2.53 & 0.69 & 0.74 & 0.72 \\
\hline $\mathbf{I}_{2} \mathbf{X} \mathbf{T}_{2}$ & 3.85 & 3.99 & 3.92 & 2.66 & 2.70 & 2.68 & 0.82 & 0.85 & 0.84 \\
\hline $\mathbf{I}_{\mathbf{2}} \mathbf{X} \mathbf{T}_{3}$ & 3.96 & 4.05 & 4.01 & 2.80 & 2.85 & 2.83 & 0.85 & 0.89 & 0.87 \\
\hline $\mathrm{I}_{2} \mathrm{X} \mathrm{T} \mathbf{T}_{4}$ & 4.03 & 4.09 & 4.06 & 2.86 & 2.93 & 2.90 & 0.90 & 0.95 & 0.93 \\
\hline $\mathbf{I}_{3} \mathbf{X} \mathbf{T}_{1}$ & 3.75 & 3.90 & 3.83 & 2.48 & 2.92 & 2.71 & 0.67 & 0.73 & 0.70 \\
\hline $\mathrm{I}_{3} \mathrm{X} \mathrm{T}_{2}$ & 3.78 & 3.98 & 3.88 & 2.60 & 2.67 & 2.64 & 0.80 & 0.84 & 0.82 \\
\hline $\mathbf{I}_{\mathbf{3}} X \mathbf{T}_{\mathbf{3}}$ & 3.83 & 4.01 & 3.92 & 2.71 & 2.69 & 2.70 & 0.83 & 0.86 & 0.85 \\
\hline $\mathbf{I}_{3} \mathbf{X T}_{4}$ & 3.89 & 4.06 & 3.98 & 2.76 & 2.73 & 2.75 & 0.88 & 0.89 & 0.89 \\
\hline L.S.D 0.05 & 0.03 & 0.04 & 0.03 & 0.04 & 0.02 & 0.04 & 0.02 & 0.02 & 0.01 \\
\hline
\end{tabular}

\section{Conclusion}

These results showed that applying irrigation water intervals of 12 days to fahl clover during two seasons under saline soil conditions could be safely practiced, which resulted an increase clover yield and it's quality. Data suggested that the application of compost at rates 5,10 and 15 ton /fad combined with irrigation water interval 12 days led to improved yield production and quality. Also, data indicated that applied compost different rate or irrigation water decreased intervals were increase of macromicronutrients available in soil and decreased soil salinity and soil $\mathrm{pH}$ during fahl clover cultivate.

In conclusion, the results obtained from this investigation, an irrigation interval 12 days combined with 5, 10 and 15 ton/fad application from compost could be recommended for fahl clover in newly reclaimed saline soil.

\section{References}

Abbas, Z. M.; F.A.F Khalil and W. M.T. Eletr (2013). Influence of water regimes and soil conditioners on yield, yield components and water utilization efficiency of Egyptian clover. J. Plant Production, Mansoura Univ. 4 (11): 16751690.
Abdel-Mawgoud, A.M.R. (2006). Growth, yield and quality of green bean (Phaseolus vulgaris L.) in response to irrigation and compost applications. J. App. Scie. Res, 2(7):443-450.

Abd El-Naby, Z. M.; N. A. Mohamed and Kh. A. Shaban (2014). Estimation of soil fertility and yield productivity of there alfalfa (Medicag ostiva L.) cultivars under sahl El-Tina saline conditions. Life . Sci. J. 10 (1): 2082 - 2095.

Abdullah, M.A. (2007). Evaluation of Some Amendments in Newly Reclaimed Soils . MSc . Thesis , Fac . of Agric Zagazig. Univ.

Al-Suhaibani, N.A. (2009) Influence of early water deficit on seed yield and quality of Faba bean under Arid Environment of Saudi Arabia. American-Eurasian J. Agric. \&Environ. Sci. 5 (5): 649-654.

Bates, L.; R.P. Waldren and I.D. Teare (1973) Rapid determination of free proline for waterstress studies. Plant and Soil, 39, 205-207.

Brunner, P.H. and H.R. Wasmer (1978) Methods of analysis of sewage sludge solid wastes and compost. W.H.O. Inte. Reference Center for Wastes Disposal (H-8600), Dulendrof Switzerland.

Chapman H.D. and P.F. Prat (1961). Methods of Analysis for Soils (Plants and Waters), the 
University of California's Division of Agriculture Sciences, Davis, Calif, USA. 148-161.

Davis, M.R.; G. coker; R.L. Parfit; R. Simcock; P.W. Clinton; L.G. Garrett and M.S. Watt (2007). Relationships between soil and foliar nutrients in young densely planted miniplots of pinusradiate and cupressus lusitanica. Forest Ecol. Manage., 240:122-130.

Dubois, M.; A. Gilles; J.K. Hamelton;P.A. Robers and P.A. Smith (1956). A colorimetric method for determination of sugar and related substances. Annals Chem., 28: 2-350-356.

El- Dakroury, M.A., (2008) Influence of different irrigation systems and irrigation treatments on productivity and fruit quality of some bean varieties M. Sc. Thesis, Fac. of Agri., Ain Shams University, Egypt.

El-Noemani, A.A.; A.A. Aboellil and O.M. Deweder (2015). Influence of irrigation systems and water treatments on growth, yield, quality and water use efficiency of bean (Phaseolus vulgaric L) plants. Intern. J. Chem. Tech. Res. 8 (12): 248- 258 .

FAO, (1992). Waste water treatment and use in agriculture. FAO Soils Bull. No.47, Rome.

Hammad, S.A.R.; Kh. A. Shaban and M. F. Tanawy (2010). Studies on salinity tolerance of two peanut cultivars in relation to growth, leaf water content. Some chemical aspects and yield. J. Appl. Sci. Res. 6 (10): 1517- 1526.

He, Y. and R. Li (2004). Effect of the organoinorgano-mixed fertilizer application on sugarcane yield and soil enzymatic activity. Sugar Crops China 4: 36-38.

Hedia, R. M. (2014). Effect of water application rate and leaching method on reclamation of a coastal salt affected soil of harawah region, Libya. Egypt. J. Soil. Sci. 54 (2): 121- 130.

Hossien-Zaden, G.; H. Jalilvand and R. Tamartash (2008). Vegetation cover changes and some chemical soil properties in pasture with different grazing intensities. Iranian. J. of Range and Desert Res. 14 : $500-512 \quad$ Hu Y.; Z. Burucs; S.V. Tucher and U. Schmidhalterm (2007). Short-term effects of drought and salinity on mineral nutrient distribution along growing leaves of maize seedlings. Environ. and Experimental Botany 60, 268-275

Hussein, M. M. and S. A. Mahmoud (2013). Evaluation of water stress on mineral status of Egyptian clover (Trifolium alexandrinum ) varieties. J. Basic. Appl. Sci. Res. 3 (12): 193198.

Hymowitz, T.F.; P. Collins and W.M. Walker (1972). Relationship between the

content of oil, protein and sugar in soybean seed. Agron. J., 64: 613-616.

Ibrahim, H. I.M.; A. M. Sallam and Kh. A. Shaban (2015). Impact of irrigation rates and potassium silicate fertilizer on seed production and quality of fahl Egyptian clover and soil properties under saline conditions. AmericanEurasian . J. Agric. \& Environ. Sci. 15 (7): 12451255 .

Ibrahim, K.H.M and O.A.S. Fadni (2013). Effect of organic fertilizers application on growth, yield and quality of tomatoes in North Kordofan (sandy soil) Western Sudan. Greener J. Agri. Sci. 3(4): 299-304.

Jiang, Y.; Y. Yao and Y. Wang (2012). Physiological response, cell wall components, and gene expression of switchgrass under shortterm drought stress and recovery. Crop Sci. 52, 2718-2727.

Kuchenmeister, K.; F. Kuchenmeister; M. Kayser; N. Wrage-Monnig and J. Isselstein (2013). Influence of drought stress on nutritive value of perennial forage legumes. Inter. J. Plant production. 7 (4): 693- 710.

Mariangela, D. and M. Francesco (2015). Effectiveness of organic wastes as fertilizers and amendments in salt - affected soils. J. Agric. 5: $221-230$.

Mazher, A. A. M.; M. H. Mahgoub; Kh. M. Abd El-Rheem and S. M. Zaghloul (2012). Influence of Nile compost application on growth, flowering and chemical composition of Amaranthus tricolor under different irrigation water intervals. Middle Est . J. Sci. Res. 12 (6): 751- 759.

Ouda A. Samiha; M. M. Ewis and M. I. Badawi (2015). Water requirements for clover and cotton under climate change condition. J. Soil Sci. and Agric. Eng., Mansoura Unvir., 6 (3): 375- 383.

Page, A. L.; R. H. Miller and D. R. Keeney (1982). "Methods of Soil Analysis" Part 2.Amer. Soc. Agron., Madison, Wisconsin, USA.

Ramezan, Z.; J. Mohammad; T. Ali; S. Hamed and S. Naser (2013). Effect of alfalfa planting in abandoned rain-feds on soil and vegetation characteristic, mane and semelghan, Iran. Inter. J. of Agric.and Plant Production. 4 (1): 57- 63.

Rashad, F. M.; H. H. Kesba; W. D. Saleh and M. A. Moselhy (2011). Impact of rice straw compost on microbial population, plant growth, nutrient uptake and root-knot nematode under greenhouse conditions. African J. Agric. Res., 6: 1188-1203.

Reda , M. M. A. (2007). Amelioration techniques for saline sodic soils in north Nile delta and its impact on sunflower productivity. J. Biol . Chem. Environ. Sci., 2: 139 - 155.

Roey, P.L P. and P. C. Jingjing (2015). Effect of different fertilizer schemes and irrigation intervals on tomatoes response to water shortage. Tropical Technology Journal. 19 (1): 1-4.

Sasani, S.; M.R. Jahansooz and A. Ahmadi (2004). The effects of deficit irrigation on Water-use efficiency, yield, and quality of forage pearl millet Proceedings of the 4th Inter. Crop Sci. Congress Brisbane, Australia, 26 Sep-1 Oct. 
Sallam, A. M.; Kh.A. Shaban and M.S. Abuhashem (2014). Influence of water deficit on seed yield and seed quality of faba bean under saline soil conditions at North Sinia, Egypt. Egypt. J. Soil. Sci. 54 (3): 265- 278.

Shaban, KH. A. (2005). "Effect of different irrigation water resources on properties and productivity of salt affected soils." Ph.D. Thesis, Fac .of. Agric., Monufiya University. Egypt

Shaban, Kh. A.; M. G. Abd El-Kader and S. M. El-Khadrawy (2011). Evaluation of organic farm and compost combined with urea fertilizers on fertility and maize productivity in newly reclaimed. Res. J. Agric. And Biol. Sci. 7 (5): 388- 397.

Snedecor, G. W. and W. G. Cochran (1980). Statistical Methods. $7^{\text {th }}$ Edition, Iowa State Univ. Press., Ames., Iowa., USA.
Turan, M. A.; H. A. AbdelKarim; T. Nilgun and T. Suleyman (2009). Effect of salt stress on growth, stomatal resistance, proline and chlorophyll concentrations on maize plant. Afric. J. Agric. Res. 4(9): 893- 897.

Wang, L.; X. Sun; S. Li; T. Zhang; W. Zhang and P. Zhai (2014). Application of organic amendments to a coastal saline soil in North China: Effects on soil physical and chemical properties and tree growth. J. Pone. 9 : 171 -185.

Zhu, Z.J.; G.Q. Wei; J, Li; Q.Q. Qian and J.Q. Yu (2004). Silicon alleviates salt stress and increases antioxidant enzymes activity in leaves of salt-stressed cucumber ( Cucumis sativus L.). Plant Sci 167:527-533. 


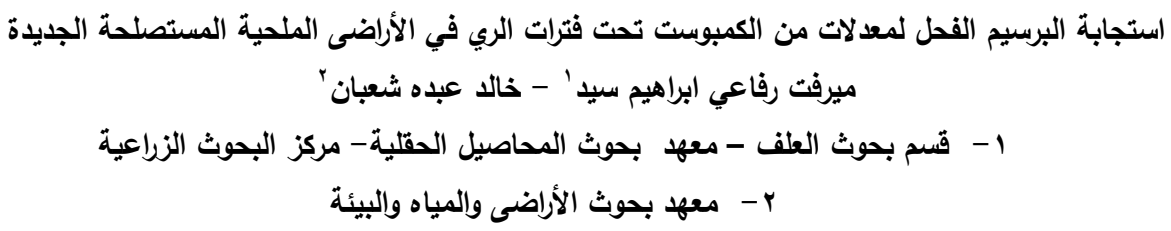

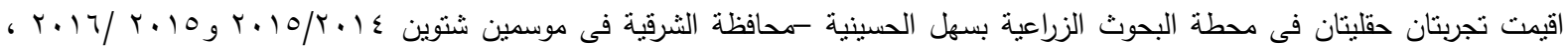

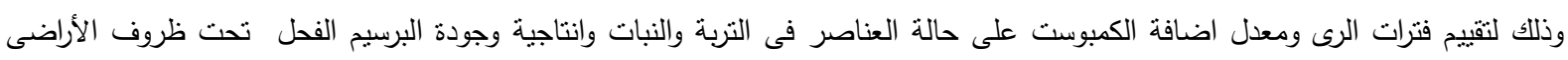

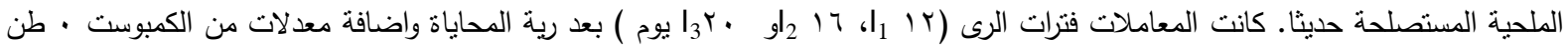

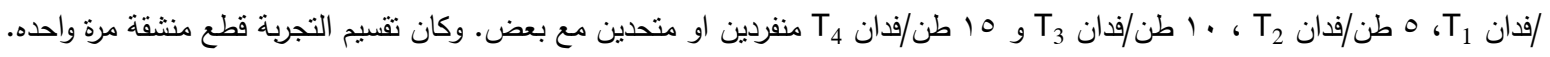
كانت نتائج التجربة كالتالى :

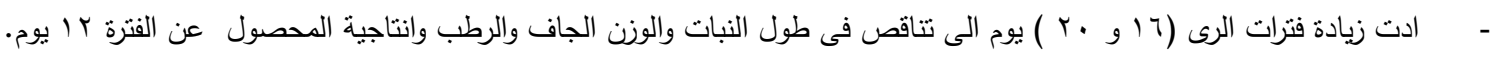

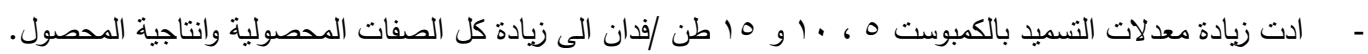

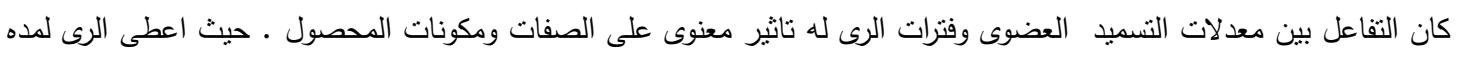
rا بوم مع جميع معدلات اضافة الكمبوست اعلى انتاجية. كان لناثير فترات الرى ناثير معنوى على تركيز العناصر الكبرى النيتروجين - الفوسفور - البوتاسيوم في النبات

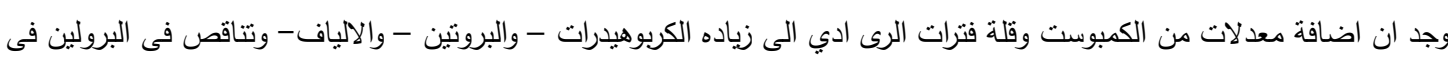
النبات.

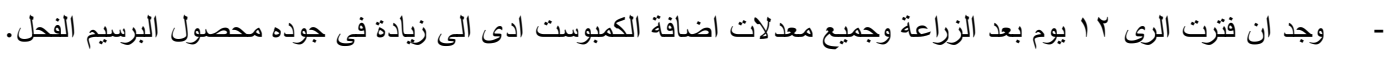

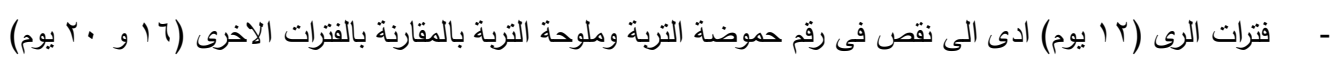

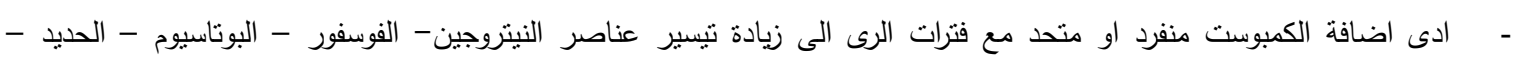
المنجنيز و الزنلك ) فى التربة بعد الحصاد. التوصية: نوصى بفترة الرى با بوم بعد رية المحاياه والتسميد بالكمبوست وزراعة البرسيم الفحل فى الاراضى الملحية حديثة الأستصلاح. 